\title{
First record of an adult Galapagos slipper lobster, Scyllarides astori, (Decapoda, Scyllaridae) from Isla del Coco, Eastern Tropical Pacific
}

\author{
Juan Carlos Azofeifa-Solano ${ }^{1 *}$, Manon Fourriére ${ }^{2,3}$ and Patrick Horgan ${ }^{4}$
}

\begin{abstract}
The Galapagos Slipper lobster, Scyllarides astori, has been reported from rocky reefs along the Eastern Tropical Pacific: the Gulf of California, the Galapagos Archipelago and mainland Ecuador. Although larval stage S. astori has been found in other localities throughout this range, there are no records of adults inhabiting waters between these three locations. Here we present the first record of an adult $S$. astori from Isla del Coco and Costa Rican Pacific waters. The single specimen, a male, was hand-collected within a coral reef in Pájara islet. This finding increases the reported lobster species richness of Costa Rican Pacific waters to six species and expands the adult geographic range of $\mathrm{S}$. astori to Isla del Coco.
\end{abstract}

Keywords: Diversity record, Coral reefs, Scyllaridae, Oceanic island, Tropical waters, Costa Rica

\section{Introduction}

Marine lobsters are a highly diverse group that includes six families, 55 genera, and 248 species that occupy a wide range of habitats and are distributed worldwide (Chan 2014; Briones-Fourzán and Lozano-Álvarez 2015). The slipper lobsters (Scyllaridae) can be distinguished from other lobster families in the infraorder Achelata by having the antennal peduncle segments wide and flat, and the antennal flagellum as a single broad and flat segment without noticeable articulations (Holthuis 1985, 1991). Slipper lobsters are bottom-dwelling decapods commonly inhabiting mud, mud-sand, sand or rocky subtidal zones (Holthuis 1985; Hearn 2006). They are known to prey on several invertebrates (Martínez 2000). Although some scyllarid species are economically important, most of them remain poorly studied (Briones-Fourzán and Lozano-Álvarez 2015).

Only two scyllarid species are registered for the Eastern Tropical Pacific (ETP): Evibacus princeps Smith, 1869 and Scyllarides astori Holthuis 1960 (Johnson 1975b;
Hendrickx 1995). The Shield Fan Lobster (E. princeps) is distributed along the Pacific coast from the Gulf of California to Peru (Johnson 1975b; Holthuis 1985; Hendrickx 1995), while $S$. astori has been reported in the Gulf of California, the Galapagos Archipelago, nearby Clipperton atoll and mainland Ecuador (Holthuis and Loesch 1967; Holthuis 1991; Hendrickx 1995; Béarez and Hendrickx 2006; Butler et al. 2013). These two species are caught incidentally in spiny lobster fisheries. Although they are not exploited for exportation, they are commercially important to local fisheries (Holthuis 1991).

Isla del Coco is an offshore Pacific island, located approximately $500 \mathrm{~km}$ away from the coast of Costa Rica. The remarkable biodiversity of this island has been studied since 1888 (see Cortés 2008), and studies of crustaceans from this remote island started in the middle of the 20th century (see Vargas and Wehrtmann 2008). A phyllosoma larva of $S$. astori was collected in the surrounding water column off the island (Johnson 1970). However, no adult scyllarid lobsters have been previously

\footnotetext{
* Correspondence: eazofeifa2@gmail.com

${ }^{1}$ Programa de Maestría en Biología, Sistema de Estudios de Posgrado,

Universidad de Costa Rica, San Pedro 11501-2060, San José, Costa Rica

Full list of author information is available at the end of the article
} 
recorded for Isla del Coco (Vargas and Wehrtmann 2008; Vargas and Wehrtmann 2009; Cortés 2012). Here we present the first record of an adult $S$. astori from Isla del Coco and extend its geographic distribution to this oceanic island.

\section{Material and methods}

Isla del Coco is one of five islands in the ETP and belongs biogeographically to the Panamic Province (sensu Boschi 2000). The island is the only protruding seamount on the Coco's Range (Lizano 2012; Rojas and Alvarado 2012). The Isla del Coco National Park was declared in 1978 and comprises the principal island, several islets and its surrounding waters that cover nearly $2000 \mathrm{~km}^{2}$ (Cortés 2008; Lizano 2012). The island and surrounding waters are affected by the seasonal movement of the Inter-Tropical Convergence Zone (Broenkow 1965; Alfaro 2008), El Niño-Southern Oscillation (Fiedler and Talley 2006), and the seasonal upwelling in the Gulf of Papagayo, Costa Rica (Lizano 2008). The neighboring waters are also chemically influenced by coastal and oceanic water bodies (Acuña et al. 2008).

The specimen was collected on October 14th 2015 during a scuba diving survey of macro-invertebrates at Isla del Coco. The single specimen was handcollected at the western side of the Pájara islet $\left(5.5535^{\circ} \mathrm{N} ;-87.0545^{\circ} \mathrm{W}\right.$ ) (Fig. 1) during twilight, at $18 \mathrm{~m}$ depth over a sandy patch within a coral reef. The specimen was stored at $0{ }^{\circ} \mathrm{C}$ before being transported to the crustacean collection of the Museum of Zoology, Universidad de Costa Rica (MZUCR), where it was preserved in $70 \%$ ethanol. The identification was carried out following Holthuis (1991). The geographic range of the species was verified based on the scientific literature (Holthuis 1960; Holthuis and Loesch 1967; Johnson 1970; Holthuis 1991; Hendrickx 1995; Hickmann and Zimmerman 2000; Béarez and Hendrickx 2006; Butler et al. 2013). After the identification, the specimen was deposited at MZUCR (3383-01). The specimen was collected under the Isla del Coco Marine Conservation Area permission: 2015-1ACMIC-018.

\section{Results}

\section{SYSTEMATICS}

Order DECAPODA Latreille, 1803

Suborder PLEOCYEMATA Burkenroad, 1963

Family SCYLLARIDAE Latreille, 1825

Genus Scyllarides Gill, 1898

Scyllarides astori Holthuis 1960

(Figure 2)

\section{Description}

The male specimen measured $26 \mathrm{~cm}$ total length, and $13 \mathrm{~cm}$ carapace length (Fig. 2a, b). Dorsal surface of carapace faintly arched, without conspicuous elevations or teeth, with wide and shallow grooves; no cervical incision of lateral margin. Median carina absent from second to fifth abdominal somites. Basal part of posterior margin of pleura of second abdominal somite concave. Carpus of first pereiopod without dorsal carinae and not swollen. Ocular peduncles bear longitudinal color stripes. First abdominal somite with smooth dorsal surface and two large nearly circular lateral dark-red spots (Fig. 2a). Between these spots, surface is yellowish with many smaller red spots placed near together, which look like another big median spot.

\section{Remarks}

The other scyllarid species reported for ETP waters, E. princeps, shows a deep cervical incision in the anterior part of the lateral margin of the carapace, and the final segment of the antennae is conspicuously crenulated (Holthuis 1991). In contrast, these characteristics are not observed in S. astori.

\section{Previous records}

Adults have been reported from the Gulf of California (Mexico), the Galapagos Archipelago and mainland Ecuador (Holthuis 1960, 1991; Hendrickx 1995; Béarez and Hendrickx 2006). A postlarva, probably of S. astori, was found 200 miles north of Clipperton atoll (Holthuis and Loesch 1967). A phyllosoma larva of S. astori was found off Isla del Coco in 1958 (Johnson 1968, 1970). Holthuis (1991) and Butler et al. (2013) stated that this species is likely to be distributed from the Gulf of California to the Galapagos Archipelago, including the ETP oceanic islands. In contrast, Hickmann and Zimmerman (2000) suggested that this species is endemic to the Galapagos Archipelago.

\section{Discussion}

There are no scientific reports of adult $S$. astori from inshore waters of Costa Rica nor Isla del Coco (Vargas and Wehrtmann 2008; Vargas and Wehrtmann 2009; Cortés 2012). Only a phyllosoma larva of $S$. astori has been recorded off Isla del Coco at $5^{\circ} 16^{\prime} \mathrm{N} ; 87^{\circ} 57^{\prime} \mathrm{W}$ (Johnson 1970). This is not surprising considering that scyllarid larvae could be transported thousands of kilometers by the ocean currents (Johnson 1968, 1970, 1975a, 1975b; Béarez and Hendrickx 2006). Therefore, the occurrence of the phyllosoma larvae in a given area does not necessarily mean that adults can inhabit and reproduce in the same area. In this paper we present the first record of an adult $S$. astori at Isla del Coco. It should be noted that dive masters visiting Isla del Coco have mentioned that 


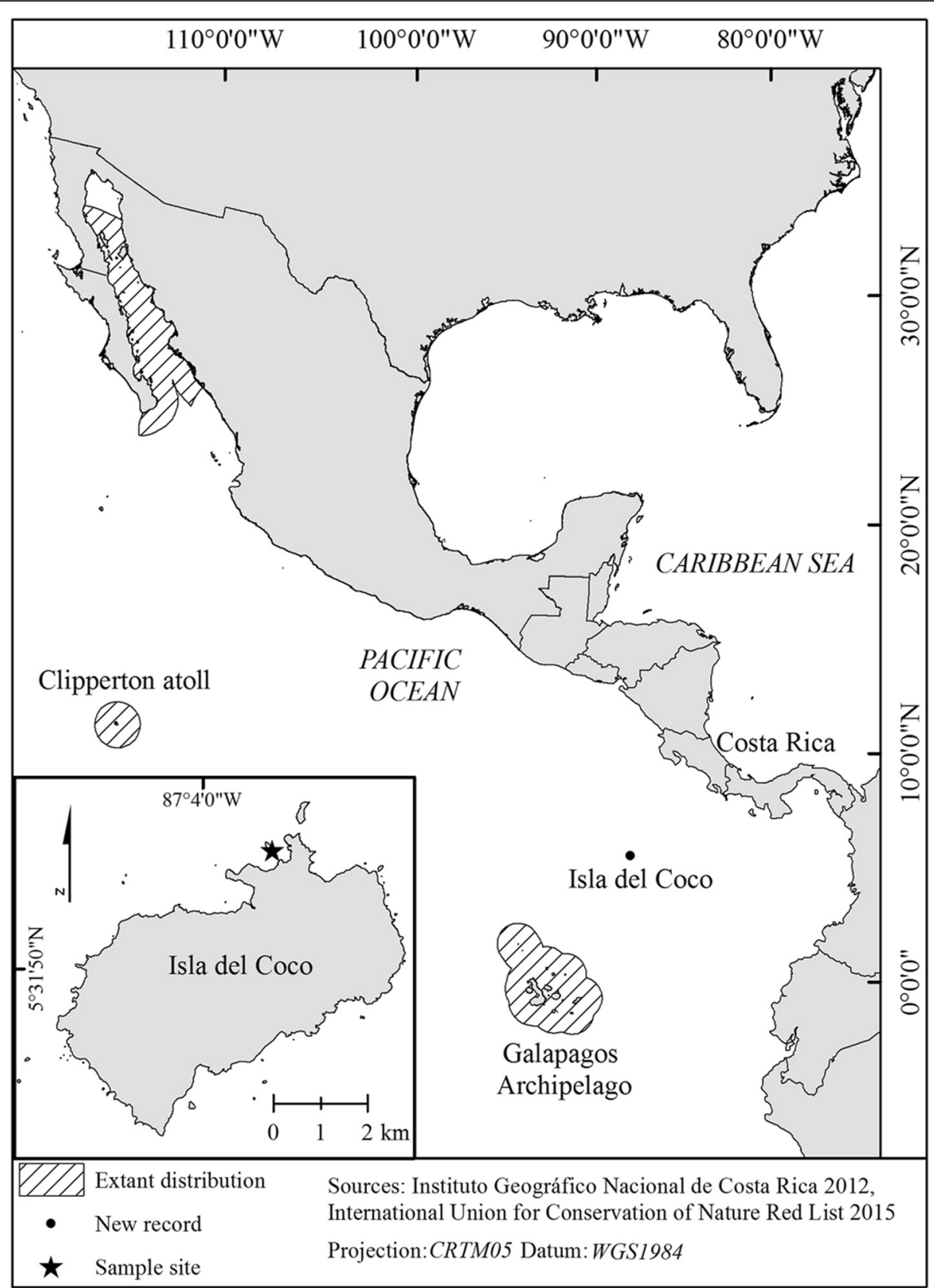

Fig. 1 Distribution of Scyllarides astori Holthuis 1960 in the Eastern Tropical Pacific. Striped area: extant distribution of S. astori obtained from IUCN Red List, circle: new record of S. astori; star: sample site at Isla del Coco

this lobster has been observed a few times during night dives. Moreover, a picture of a Galapagos Slipper Lobster was taken at Isla del Coco by Franco Banfi in 2009 and is posted in the web (www.banfi.ch). This implies that there is probably an established population of $S$. astori in Isla del Coco. The presence of adult specimens of $S$. astori in scattered sites in the Gulf of California, and Ecuador, suggests that settlement of juveniles and survival of adults might be more likely in colder temperate/ subtropical waters (Béarez and Hendrickx 2006). However, the new record found in Isla del Coco shows that adult $S$. astori could also inhabit warm tropical waters.

Although the biology of $S$. astori has been well studied in the Galapagos Archipelago (Holthuis and Loesch 1967; Martínez 2000; Hearn 2006; Hearn and ToralGranada 2007), there is no information about population dynamics nor trophic ecology of this species in locations outside the Galapagos. Moreover, it is important to note 


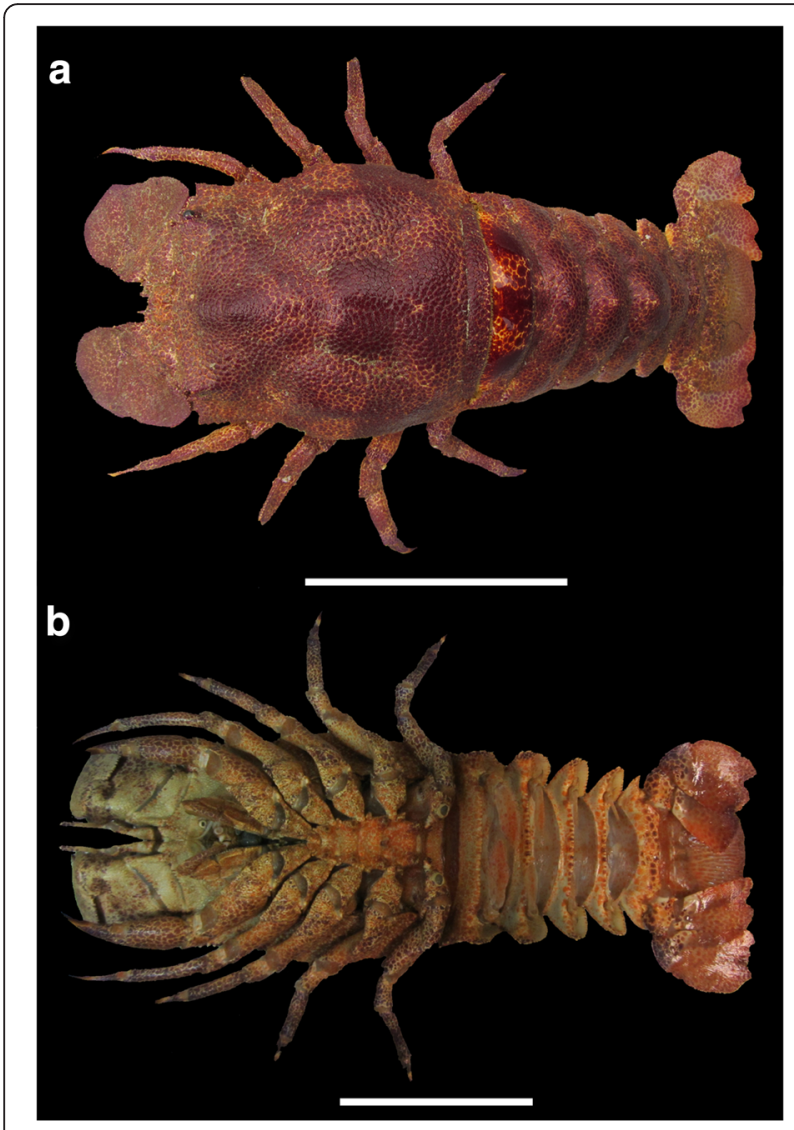

Fig. 2 Male of Scyllarides astori Holthuis 1960: a) dorsal view, b) ventral view. Scale $=10 \mathrm{~cm}$. Catalog number MZUCR 3383-01 of the Museum of Zoology, Universidad de Costa Rica

that this species is reported as data deficient by the IUCN (Butler et al. 2013), and its commercial interest in Galapagos lobster fisheries has recently increased due to the depletion of spiny lobsters (Martínez et al. 2002; Hearn 2004; Murillo et al. 2004). Therefore, the population of Isla del Coco could represent an opportunity to evaluate growth models and reproductive aspects of $S$. astori in a protected area without fisheries impacts.

Reporting the presence of new species in Isla del Coco, even after many scientific expeditions have been carried out, reemphasizes the importance and necessity of continued research at this island. Finally, the finding increases the reported diversity of Costa Rican Pacific lobster from five to six species (Vargas and Wehrtmann 2009).

\section{Acknowledgements}

We are very grateful to Área de Conservación Marina Isla del Coco (ACMIC) for all of their support during the fieldwork portion of this study (especially to Isaac Chinchilla and Esteban Herrera). Rita Vargas assisted us in identifying the specimen, which is gratefully acknowledged. We would like to thank Juan José Alvarado and Jorge Cortés who supported the logistics of the survey. We are especially grateful to Ingo Wehrtmann, Juan José Alvarado and Arturo Ayala Bocos for their comments on the manuscript. We are grateful to the IUCN Red List and Instituto Geográfico Nacional de Costa Rica for providing geographic information used in the map. We are grateful to Juan Manuel Camargo who helped us to confirm the observations of the dive masters. Thanks to the Leibniz Center for Tropical Marine Ecology (ZMT) for the financial contribution to the field work. We are very grateful for the comments received from the reviewers that helped to improve the quality of this paper.

\section{Authors' contribution}

All authors contributed with sampling and drafting of the manuscript. Specimen was collected by PH. Specimen identified by JCAS and MF. All authors read and approved the final manuscript.

\section{Competing interests}

The authors declare that they have no competing interests.

\section{Author details}

${ }^{1}$ Programa de Maestría en Biología, Sistema de Estudios de Posgrado, Universidad de Costa Rica, San Pedro 11501-2060, San José, Costa Rica. ${ }^{2}$ Centro de Investigación en Ciencias del Mar y Limnología (CIMAR), Ciudad de la Investigación, Universidad de Costa Rica, San Pedro 11501-2060, San José, Costa Rica. ${ }^{3}$ International Studies in Aquatic Tropical Ecology Program (ISATEC-Master candidate), Bremen University, Bremen, Germany. ${ }^{4}$ School of Biological Sciences, The University of Queensland, St Lucia, QLD 4072, Australia.

Received: 4 February 2016 Accepted: 3 June 2016

Published online: 30 June 2016

\section{References}

Acuña J, García J, Gómez E, Vargas JA, Cortés J. Parámetros físico-químicos en aguas costeras de la Isla del Coco, Costa Rica (2001-2007). Revista de Biología Tropical. 2008;56 Suppl 2:49-56.

Alfaro EJ. Ciclo diario y anual de variables troposféricas y oceánicas en la Isla del Coco. Costa Rica Revista de Biología Tropical. 2008;56 Suppl 2:19-29.

Béarez P, Hendrickx ME. First record of Scyllarides astori Holthuis, 1960 (Crustacea, Decapoda, Scyllaridae) from mainland Ecuador. Contributions to the Study of East Pacific Crustaceans. 2006;4:109-12.

Boschi EE. Species of decapod crustaceans and their distribution in the American marine zoogeographic provinces. Revista de Investigación y Desarrollo Pesquero. 2000;13:1-136

Briones-Fourzán P, Lozano-Álvarez E. Lobsters: ocean icons in changing times. ICES Journal of Marine Science. 2015;72:1-6.

Broenkow WW. The distribution of nutrients in the Costa Rica Dome in the Eastern Tropical Pacific Ocean. Limnology and Oceanography. 1965;10:40-52.

Butler M, Cockcroft A, MacDiarmid A. Scyllarides astori. The IUCN Red List of Threatened Species. 2013; doi:10.2305/IUCN.UK.2011-1.RLTS. T170020A6709551.en.

Chan TY. Annotated checklist of the world's marine lobsters (Crustacea: Decapoda: Astacidea, Glypheidea, Achelata, Polychelida). The Raffles Bulletin of Zoology. 2014;23:153-81.

Cortés J. History of marine research at Cocos Island, Costa Rica. Revista de Biología Tropical. 2008;56 Suppl 2:1-18.

Cortés J. Marine biodiversity of an Eastern Tropical Pacific oceanic island, Isla del Coco, Costa Rica. Revista de Biología Tropical. 2012;60 Suppl 3:131-85.

Fiedler PC, Talley LD. Hydrography of the eastern tropical Pacific: A review. Progress in Oceanography. 2006;69:143-80.

Hearn A. Evaluación de las poblaciones de langostas en la Reserva Marina de Galápagos. Informe Final 2002-2004. Galápagos, Ecuador: Fundación Charles Darwin and Dirección Parque Nacional Galápagos; 2004.

Hearn A. Life history of the slipper lobster Scyllarides astori Holthuis 1960, in the Galapagos Islands, Ecuador. Journal of Experimental Marine Biology and Ecology. 2006;328:87-97.

Hearn A, Toral-Granada MV. Reproductive biology of the Red Spiny Lobster, Panulirus penicillatus and the Galapagos Slipper Lobster, Scyllarides astori in the Galapagos Islands. Crustaceana. 2007;80:297-312.

Hendrickx ME. Langostas. In: Fischer W, Krupp F, Schneider W, Sommer C, Carpenter KE, Niem VH, editors. Guía FAO para la Identificación de Especies para los Fines de la Pesca. Pacífico Centro-Oriental. Rome: FAO; 1995. p. 383-415. 
Hickmann CP, Zimmerman TL. A field guide to crustaceans of Galapagos. An Illustrated Guidebook to the Common Barnacles, Shrimps, Lobsters and Crabs of the Galapagos Islands. Lexington, USA: Sugar Spring Press; 2000.

Holthuis LB. Preliminary descriptions of one new genus, twelve new species and three new subspecies of scyllarid lobsters (Crustacea Decapoda Macrura). Proceedings of the Biological Society of Washington. 1960;73:147-54.

Holthuis LB. A revision of the family Scyllaridae (Crustacea Decapoda Macrura). I. Subfamily Ibacinae. Zoologische Verhandelingen. 1985;218:1-130.

Holthuis LB. FAO species catalogue. Vol. 13. Marine lobsters of the world. An annotated and illustrated catalogue of species of interest to fisheries known to date. Rome: Food and Agriculture Organization; 1991.

Holthuis LB, Loesch B. The lobsters of the Galápagos Islands (Decapoda, Palinuridea). Crustaceana. 1967;12:214-22.

Johnson MW. The phyllosoma larvae of scyllarid lobsters in the Gulf of California and off Cental America with special reference to Evibacus princeps (Palinuridea). Crustaceana. 1968;Suppl. 2:98-116.

Johnson MW. On the phyllosoma larvae of the genus Scyllarides Gill (Decapoda, Scyllaridae). Crustaceana. 1970;18:13-20.

Johnson MW. A supplementary note on the larvae of Scyllarides astori Holthuis (Decapoda, Scyllaridae). Crustaceana. 1975a;28:109-12.

Johnson MW. The postlarvae of Scyllarides astori and Evibacus princeps of the Eastern Tropcal Pacific (Decapoda Scyllaridae). Crustaceana. 1975b;28:139-44.

Lizano OG. Dinámica de aguas alrededor de la Isla del Coco, Costa Rica. Revista de Biología Tropical. 2008;56 Suppl 2:31-48

Lizano OG. Rasgos morfológicos alrededor de la Isla del Coco y de sus montes submarinos vecinos, Pacífico de Costa Rica. Revista de Biología Tropical. 2012;60 Suppl 3:43-51.

Martínez CE. Ecología trófica de Panulirus gracilis, P. penicillatus y Scyllarides astori (Decapoda, Palinura) en sitios de pesca de langosta en las islas Galápagos. Universidad del Azuay, Ecuador: Bachelor's degree thesis; 2000.

Martínez CE, Toral-Granda MV, Edgar GJ. Langostino. In: Danulat E, Edgar GJ, editors. Reserva Marina de Galápagos, Línea Base de la Biodiversidad. Galápagos, Ecuador: Fundación Charles Darwin and Servicio Parque Nacional Galápagos; 2002. p. 216-32.

Murillo J, Nicolaides F, Reyes H, Moreno J, Molina L, Chasiluisa C, Bautil B, Villalta M, García L, Ronquillo J. Estado pesquero y biológico de las dos especies de langosta espinosa en el año 2003. Análisis comparativo con las pesquerías 1997-2002. Evaluación de las pesquerías en la Reserva Marina de Galápagos. Informe Compendio 2003. Galápagos, Ecuador: Fundación Charles Darwin and Dirección Parque Nacional Galápagos; 2004. p. 50-102.

Rojas W, Alvarado GE. Marco geológico y tectónico de la Isla del Coco y la región marítima circunvecina, Costa Rica. Revista de Biología Tropical. 2012;60 Suppl 3:15-32.

Vargas R, Wehrtmann IS. Stomatopods and decapods from Isla del Coco, Pacific Costa Rica. Revista de Biología Tropical. 2008;56 Suppl 2:79-97.

Vargas R, Wehrtmann IS. Decapod crustaceans. In: Wehrtmann IS, Cortés J, editors. Marine Biodiversity of Costa Rica, Central America. Berlin: Springer Science + Business Media BV; 2009. p. 209-28

\section{Submit your next manuscript to BioMed Central and we will help you at every step:}

- We accept pre-submission inquiries

- Our selector tool helps you to find the most relevant journal

- We provide round the clock customer support

- Convenient online submission

- Thorough peer review

- Inclusion in PubMed and all major indexing services

- Maximum visibility for your research

Submit your manuscript at www.biomedcentral.com/submit

) Biomed Central 